\title{
KÖHALMI LÁSZLÓ
}

\section{Gondolatok a vallási indíttatású terrorizmus ürügyén}

A terrorizmus tipologizálása számtalan szempont szerint lehetséges ${ }^{1}$. A témában mértékadó szakirodalmi klasszifikációk úgynevezett hármas ${ }^{2}$ vagy négyes ${ }^{3}$ felosztást használnak.

Az említett kategóriák szerinti elemzéskor felvetődhet a kérdés, hogy ezek közül vajon melyik okoz nagyobb társadalmi károkat, melyik követel több áldozatot. A vallási indíttatású terrorista attak vajon több áldozatot követel, mint a szociálforradalmi vagy az etnikai-nacionalista jellegủ terrorizmus? Az úgynevezett iszlám terrorizmus pedig még azon belül is egy különösen veszélyes fajtája a különböző formát öltő vallási jellegü terrorizmusnak. ${ }^{4}$

A problémák már rögtön itt kezdődnek, hiszen egyes szerzök szerint a terrorizmus szót nem lenne szabad használni egy világvallás nevével jelzős szerkezetben, mert azonosítja az iszlám vallás mintegy másfél milliárd követőjét egyetlen ideológiával, és az ahhoz rendelt eszközzel (ami jelen esetben a fegyveres harc). ${ }^{5}$

\footnotetext{
1 Christian Walter: Defining Terrorism in National and International Law. In: Christian Walter - Silja Vöneky - Volker Röben - Frank Schorkopf (eds.): Terrorism as a Challenge for National and International Law: Security versus Liberty? Springer, Berlin-Heidelberg, 2004, pp. 24-29.; Quénivet, rendkívül találóan, a terrorizmus definícióját egy véget nem érő történethez hasonlítja. Lásd Noëlle Quénivet: The World after September 11: Has It Really Changed? The European Journal of International Law, vol. 16, no. 3, 2015, pp. 562-563.; Bartkó Róbert: A terrorizmus elleni küzdelem kriminálpolitikai kérdései. Universitas-Győr Nonprofit Kft., Győr, 2011, 21-22. o.

2 Hans-Dieter Schwind: Kriminologie. 21. neu bearbeitete und erweiterte Auflage. Kriminalistik Verl., Heidelberg, 2011, S. 655-656. Schwind tipológiája a következö: 1. állami terrorizmus; 2. forradalmi terrorizmus; 3 . vallásilag motivált terrorizmus.

3 Korinek László: A terrorizmus. In: Fenyvesi Csaba - Herke Csongor (szerk.): Emlékkönyv Vargha László egyetemi tanár születésének 90. évfordulójára. Studia Iuridica Auctoritate Universitatis Pécs Publicata 132. Pécs, 2003, 170-171. o. Korinek László a következő tipológiát követi: 1. ideológiai indíttatású terrorizmus (szélsőbaloldali/szélsőjobboldali csoportok); 2. etnikai, faji, vallási terrorizmus; 3. állami terrorizmus; 4 . ,kiválasztottak” terrorizmusa.

4 Peter Waldmann: IslamistischerTerrorismus. Kriminalistik, 12/2014., S. 740.

5 Csicsmann László: A magyarországi muszlim kisebbségek társadalmi integrációjának kihívásai az európai tapasztalatok tükrében. In: Hollán Miklós (szerk.): Két konferencia a hatékony államról - a hatékony államért. Budapesti Corvinus Egyetem, Budapest, 2012, 60-63. o.
} 
Szemantikai pontatlansága ellenére az iszlám terrorizmus kifejezés mégis olyannyira meghonosodott mind a tudományos, mind a laikus felhasználóknak szánt publicisztikákban, hogy nehéz lenne mellőzni a használatát.

A magunk részéről tehát az ,iszlám terrorizmus” megnevezést olyan értelemben használjuk, hogy abba nem értjük bele a muszlim hívők globális közösségét, hanem redukáljuk arra a szük személyi körre, amelynek tagjai az iszlám vallás ideológiáját eltorzítva, saját személyes elömenetelük érdekében kiragadnak és elferdítve értelmeznek különböző hittételeket. ${ }^{6}$

A közelmúlt vallási elöjelü terrorcselekményeinél kétségtelenül megfigyelhető, hogy magasba szökött a merényletenkénti áldozatok száma. Peter Waldmann szerint azonban nem biztos, hogy ez kizárólag vagy elsősorban a merényletek vallásos jellegének tulajdonítható.? Úgy is érvelhetnénk, hogy egy olyan világban, amelyben az erőszak ${ }^{8}$ egyre hangosabb, csak az a terrorista csoport tud széles visszhangra ${ }^{9}$ találni, amelyik különösen kegyetlen módon támad (ez pedig a merénylet formájában és/vagy az áldozatok számában mutatkozhat meg), tehát a legújabb terrorhullámba úgyszólván immanensen be van építve egy fokozódási kényszer ${ }^{10}$, mert minden elem, illetve csoport konkurenciaharcban áll egymással a nyilvánosság figyelméért. ${ }^{11}$

Ez pedig ugyancsak összefügg a terrorizmus globalizációjával ${ }^{12}$, tehát a nemzetközi jelleggel müködő csoportok szaporodásával, aminek erőszakot felszabaditó jellege van. E nemzetközi terrorista csoportok esetében ugyanis hiányzik az egy bizonyos miliöre vagy politikai projektre való szociális viszszacsatolás ${ }^{13}$, ami általában visszafogó, fékező hatással bír. ${ }^{14} \mathrm{~A}$ lényegi ösz-

\footnotetext{
6 Lényegében hasonló véleményt fogalmaz meg Fischl. Lásd Fischl Vilmos: Iszlám és terrorizmus, avagy civilizációk összecsapása? Hadtudomány, 2011/1., 76. o.

7 Peter Waldmann: i. m. 740. o.

8 Robin L. Thompson: Radicalization and the Use of Social Media. Journal of Strategic Security, vol. 4, no. 4, 2011, pp. 167-170.

9 Korinek László: Az antiterrorista harc eszközei, különös tekintettel a büntetőjogra. In: Gál István László - Köhalmi László (szerk.): Emlékkönyv Losonczy István professzor halálának 25. évfordulójára. Studia Iuridica Auctoritate Universitatis Pécs Publicata 138. 2005, 193-194. o.

10 Brian Michael Jenkins: The US response its terrorism and its implications for transatlantic relations. In: Gustav Lindstrom (ed.): Sift or Rift - Assessing US-EU relations after Iraq. Institute for Security Studies. Paris, 2003, pp. 210-212.

11 Peter Waldmann: Das terroristische Kalkül und seine Erfolgsaussichten. Velbrück Online Magazin, 2002, S. 1-52.; Dominic Rohner - Bruno S. Frey: Blood and Ink! The common-interest-game between terrorists and the media. Public Choice, vol. 133, iss. 1-2, 2007, pp. 129-134.

12 Ekkart Zimmermann: Globalization and Terrorism. European Journal of Political Economy, vol. 27, 2011, 152-153.

13 Michael B. Salzman: Globalization, religious fundamentalism and the need for meaning. International Journal of Intercultural Relations, vol. 32, 2008, pp. 318-327.

14 Peter Waldmann (2014): i. m. 740.
} 
szefüggés tehát az, hogy a vonatkozási csoport hiánya esetén az erőszak generálódik, függetlenül a terroristák vallásos vagy anélküli indíttatásától.

A nyitott kérdés a következő: a vallási elköteleződés a terrorizmus egyéb formáihoz képest különösen nagyszámú véráldozatot követel-e?

Úgy tünik, hogy magukkal sok embert a halálba rántó vallásos terroristák tetteire adott magyarázatok is csak bizonyos feltételek mellett igazak. Bruce Hoffmann kutatásai szerint a vallásos motiváltságú merénylők bizonyos tekintetben fél lábbal már a túlvilágon vannak; kizárólag a saját örök üdvösségükre koncentrálva megszakították az e világhoz kapcsolódó hidat, és ezért már semmi sem gátolja őket abban, hogy számos embert rántsanak magukkal a halálba. ${ }^{15}$

Kézenfekvő, hogy az efféle meggondolások nem alkalmazhatók olyan terrorszervezetekre, amelyek toborozzák, képzik és oktatják a vallásos merénylöket; mert ezek a szervezetek - még a vallásos irányultságúak is - mindig e világ céljait követik.

Thomas Scheffler szerint mindez érvényes, sőt különösen érvényes az alKaidára is ${ }^{16}$, de merényletük során ${ }^{17}$, ahogy azt ma már tudjuk, az egyes vallásilag elszánt terroristák sem csak a túlvilágra gondolnak, hanem földi indítékok is mozgatják őket: olyan indítékok, amelyek személyes dicsőségüket célozzák meg - ha megfelelően teljesítik az ígéretüket -, az ő becsvágyukat, és azt a vágyukat, hogy dicső mártírként ${ }^{18}$ éljenek tovább a közösség emlékezetében, valamint családjuk tekintélyének kivívása és megélhetésének megteremtése. ${ }^{19}$

Vajon a másik két egyistenhitủ valláshoz, a zsidó és a keresztény valláshoz képest az iszlámra különös agresszivitás jellemzö-e?

A kérdésre Waldmann szerint egy gondolatkísérlettel adható meg a válasz. Tételezzük fel, hogy 465 évvel ezelőtt járunk, úgy 1550 tájékán. Ez volt az az időszak, amikor a spanyolok, miután elüzték a mórokat az Ibériai-félszi-

\footnotetext{
15 Bruce Hoffmann: „Holy Terror”: The Implications of Terrorism Motivated by a religious Imperative. Studies in Conflict \& Terrorism, vol. 18, iss. 4, 1995, pp. 271-275.

16 Thomas Scheffler: “Apocalypticism, Inner worldly Eschatology, and Islamic Extremism”. In: BellérHann, Ildikó - Lisette Gebhardt (eds.): Religion und Gewalt: Japan, der Nahe Osten und Südasien. Orientwissenschaftliches Zentrum der Martin-Luther-Universität Halle-Wittenberg, 2003, S. 43-79. [Orientwissenschaftliche Hefte, Nr. 10.]; lásd még Nagy Mihály: Az al-Kaida és „testvérszervezeteinek” előretörése a Maghreb-térségben. Nemzet és Biztonság, 2011/5., 15-17. o.

17 Michael Draeger: Die Al-Qaida - eine Reaktion auf die Globalisierung? Grin Verlag, München, 2008, S. 3-9.

18 Korinek László (2003): i. m. 171. o.

19 Thomas Scheffler: Mit Extremisten verhandeln: Weshalb, wann und wie? In: Dialog mit der islamischen Welt. Auswärtiges Amt. Edition Diplomatie, Berlin, 2005, S. 79-81.
} 
getről, a katolikus királyok nevében tüzzel és vassal meghódították DélAmerikát, és a keresztény Európa is azon volt, hogy az egész világra kiterjessze a hatalmát.

Abban az időben vélhetően egy fordított tartalmú ítélet született volna, miszerint a keresztény vallás militáns és háborús vallás, a visszaszoruló iszlám pedig szelíd és pacifista. ${ }^{20}$

A kereszténység önmagát a szeretet vallásaként definiálja, $\mathrm{s}$ az iszlám explicit módon igent mond a vallásháborúra, emellett sok más vallás is formailag erőszak-metaforáktól duzzad. ${ }^{21} \mathrm{Az}$ emberiség történelmében az ideológia és a gyakorlat, a retorika és a viselkedés két külön dolog. Harcos pátosza ellenére az iszlám hosszú időn keresztül az önmérséklet és a felelösségtudat vallása volt, ezzel szemben a keresztény uralkodók nem riadtak vissza attól, hogy céljaikat messze nem keresztény módszerek segítségével valósítsák meg.

Az ismert brit iszlámkutató, Bernard Lewis szerint a két hitközösség semmiben sem maradt adósa egymásnak, mindkettő olyan történelemre tekinthet vissza, amelyet egyaránt átsző a békére törekvés és az eröszakkeltés, az igazság megvédése, valamint a kézzelfogható igazságtalanságra való biztatás. ${ }^{22}$

A monoteista vallásokat - Waldmann szerint - az ambivalencia jellemzi, mindhárom világvallás (keresztény, iszlám, zsidó) teremthet megbékélést és egyetértést, de lehet az üldözés, elnyomás és szociális kirekesztés hajtóereje is. ${ }^{23}$

A kérdés nem az, hogy végső soron melyik ér el jobb eredményt, hanem hogy mikor és mindenekelött milyen körülmények között kap hangsúlyt az egyik vagy a másik pólus. Hiszen nyilvánvalóan az összes vallás fel tud mutatni olyan időszakokat, amelyekben inkább a civilizált, békét és kiegyezést hangsúlyozó összetevői érvényesülnek, és olyan időszakokat is, amelyekben pedig a gyülölet és a széthúzás forrásaiként szolgálnak.

Scott Appleby szerint azok a vallásos mozgalmak, amelyek szociális környezetükkel alapvetően békés viszonyra törekednek, bizonyos körülmények között mégis hirtelen erőszakos eszközökhöz folyamodnak. Mindezt az úgynevezett ,exceptionalizmussal” magyarázza: ha a végsőkig sarokba szorítva, egzisztenciájukban fenyegetve érzik magukat, az különböző fundamenta-

20 Peter Waldmann (2014): i. m. 741. o.

21 Detre Zoltán: A terrorizmus kialakulásának történeti háttere, megnyilvánulási formái és jelenléte a XXI. században. Bolyai Szemle, 2007/2., 78-80. o.

22 Bernard Lewis: The Crisis of Islam - Holy War and Unholy Terror. Modern Library Edition, New York, 2003, pp. 138-145.

23 Peter Waldmann (2014): i. m. 741. o. 
lista ${ }^{24}$ hitközösségek számára olyan kivételes helyzetet teremthet, amelyben bizonyos fokig feje tetejére állnak, ellenkezőjükbe fordulnak át a megszokott értékek és a viselkedés irányultsága.

Még ha alapvetően az embertársak és más csoportok iránti szolidaritás és tolerancia a jelmondatuk, akkor is, a kivételes helyzet fényében az embertársakból és a hatalom képviselöiből hirtelen árulók vagy ellenségek lesznek, akiket együttérzés nélkül meg kell támadni és meg kell semmisíteni. Appleby ezzel magyarázza meg, hogy miért látták a különböző fundamentalista csoportok - mint az izraeli Gush Emunim, az amerikai keresztény milícia egy része, vagy az egyiptomi iszlám csoportok - a kormány képviselőiben hirtelen a gonosz megtestesülését, amellyel szemben a legnagyobb kíméletlenséggel eljárni szent kötelességük volt. ${ }^{25}$

Ennek a megközelítésnek feltétlen előnye a mentesség a ködös spekulációkba bocsátkozástól. Nem próbál erőltetett módon a különböző vallásokban szunnyadó ,, démonikus potenciálokat” keresni, hanem a „kivételes helyzet" alakjában megnevez egy konkrét, empirikusan felülvizsgálható kritériumot arra, hogy mikor számolhatunk egy vallási csoport részéről vehemens, adott esetben erőszakos reakcióval. Olyan kritériumról van szó, amelyet nem lehet kiolvasni elsődlegesen külső körülményekböl, hanem az igazolásához behatóan kell foglalkozni azzal, vajon mi zajlik a hívők fejében.

Appleby arra is rámutat, hogy a valódi fundamentalista mozgalmak viszonylag ritkák, ezzel szemben sokkal gyakoribb, hogy a vallásos elhivatottság egyéb motívumokkal keveredik, ezeket megerősíti és radikalizálja. ${ }^{26}$

Mark Juergensmeyer ezt abban a kérdésben foglalja össze, hogy mikor áll fenn annak a veszélye, hogy a világi, például etnikai-nemzeti vagy szociális jellegű konfliktusok vallásilag túlforrósodnak és , kozmikus háborúvá ${ }^{27}$ fajulnak.

Három olyan körülményt nevez meg, amelyek valószínüsítik egy ilyen vallási töltet kialakulását:

- Elöször is, ha elemi javakkal kapcsolatos konfliktusról van szó, mint amilyen például az identitás és a kollektív méltóság megvédése.

\footnotetext{
24 R. Scott Appleby: The Ambivalence of the Sacred: Religion, Violence, and Reconciliation. Rowman \& Littlefield Publishers, Lanham, 2000, pp. 80-91.; bővebben lásd Michael O. Emerson - David Hartman: The Rise of Religious Fundamentalism. Annual Review of Sociology, vol. 32, 2006, pp. $133-135$.

25 Peter Waldmann (2014): i. m. 741. o.

26 R. Scott Appleby: Religious Violence: The Strong, the Weak, and the Pathological. Practical Matters, iss. 5, 2012, p. 3.

27 Mark Juergensmeyer: Terror in the Name of God. Current History, November 2001, p. 357.
} 
- Másodszor olyan harcról kell hogy szó legyen, amelynek során elfogadhatatlan, végső soron elképzelhetetlen a vereség.

- Harmadszor egyértelmünek kell lennie, hogy ezt a harcot az adott körülmények között, ezen a világon, előrelátható időn belül semmiképpen sem lehet megnyerni; e körülmények között kézenfekvő az áthelyezés egy túlvilági szférába, ahol a konfliktus kimenetele Isten akaratától függ, és a győztesek/legyőzöttek viszonya megfordulhat. ${ }^{28}$

Nem nehéz olyan példákat találni, amelyek alátámasztják Juergensmeyer feltételezését. Gondoljunk például a palesztinokra, akiknek az Izraellel kapcsolatos ellenállása évtizedeken át szocialista jellegü volt, és akik jórészt „,csak” az elmúlt húsz évben, elsősorban a második intifáda alatti kétségbeesett akcióban vettek iszlám irányt; vagy pedig gondoljunk a csecsenek eredetileg elsősorban etnikai-nacionalista mozgalmára, ök egyebek között feltételezhetően a szabadságharcuk kilátástalansága miatt kezdték el azt vallásossá felmagasztosítani. ${ }^{29}$

Az eredetileg vallásos, elvileg békés mozgalom erőszakba való átfordulásában, és a világi konfliktusok vallásos üdvösségelképzelésekkel való felruházásában és felszításában is kulcsszerep jut a vallási vezetőknek. ${ }^{30}$ Ök azok, akik értelmezik a szent szövegeket, kulcskövetkeztetéseket vonnak le belölük, és ennek megfelelően befolyásolják a vallásos tömeget.

\section{A terrorszervezetek támogatási potenciáljának néhány szempontja}

A szociális miliö, az anyacsoportok, amelyekből kinőnek és amelyektől támogatást kapnak a terrorista elemek, központi jelentőségű azok fennmaradásához. ${ }^{31}$ Habár a terroristákra nem ugyanaz érvényes, mint a gerillákra, vagyis hogy a sikeres ellenállás előfeltételeként a lakosság körében kell mozogniuk, mint „hal a vízben”, le kell szögezni azonban: egy terrorszerve-

\footnotetext{
28 Mark Juergensmeyer: Terror in the Mind of God - The Global Rise of Religious Violence. Third Edition Revised and Updated. University of California Press, Berkeley-Los Angeles-London, 2003, pp. 148-151.

29 Mark Juergensmeyer (2001): i. m. 357-358. o.

30 R. Scott Appleby (2000): i. m. 55-58. o.

31 A terrorizmus finanszírozásának témájáról bővebben lásd Gál István László: A XXI. század új büncselekménytípusa: a terrorizmus finanszírozása. Rendészeti Szemle, 2009/6., 61-65. o.
} 
zetnek nincsenek jó kilátásai közép- és hosszú távon ${ }^{32}$ a népesség egy bizonyos része nélkül, egy szükebb, a terroristák mögött álló vonatkoztatási csoport nélkül, amelyből utánpótlást toborozhatnak.

$\mathrm{Az}$ iszlám terrorizmus tekintetében mindenekelőtt két nagy csoport jön számításba támogatási környezetként. Egyrészt az észak-afrikai és a közel- és távol-keleti muszlim lakosság, másrészt a muszlim diaszpóra közösségei, amelyek számos nyugati ipari társadalomban bevándorlás nyomán alakultak ki.

Ami az iszlám kultúrkörhöz tartozó országok és népcsoportok helyzetét illeti, őrizkedni kell a gyors és általánosító ítélettől. Itt sok minden függ a konkrét szociális és politikai viszonyoktól ${ }^{33}$, például hogy a muszlimok többségben vannak-e, vagy csak kisebbséget képviselnek; hogy az érintett rezsim tekintélyuralmi-e, vagy elnyomó jellegü, vagy esetleg nyitott-liberális; hogy valláspolitikailag semlegesként viselkedik-e, vagy az alkotmányába felvett iszlám elemeket, vagy netán - mint például Irán - kváziteokratikus vonásokat is mutat.

Figyelmesnek kell lenni, mert - Peter Waldmann szavaival élve - visszatérő merényletek ,,lopporfüstje” homályosítja el a látást ezekben az országokban, Marokkótól a Fülöp-szigetekig, és megnehezíti a tájékozódást, hogy mi is a helyzet az érintett népcsoportok érzületeivel. ${ }^{34}$

Ha névértéken elfogadjunk a militáns iszlamisták kijelentéseit, akkor ők mindenütt előretörőben vannak. Az internet tele van iszlám diadalgesztusokkal és győzelmi jelentésekkel. A vonatkozó újságcikkek pontos elolvasása azonban szkeptikussá teszi az embert, például a marokkói lakosság nagy része szégyellte magát honfitársai 2004. március 11-i madridi merénylete miatt; a vallási fanatikusok 2004. szeptember 9-i, a jakartai ausztrál nagykövetség elleni merénylete a népesség körében dühöt és felháborodást keltett, mert a merényletben sok indonéz is odaveszett.

Vagy említhetném azt az esetet is, amikor a luxori turisták ellen merényletet elkövető egyiptomi terroristákat a lakosság szolgáltatta ki a hatóságoknak.

Nyilvánvalóan a muszlim lakosság ezekben az országokban is csak meghatározott mértékig támogatja a terrorista akciókat.

Tehát ismétlődik, amit számos terrorista csoport általános jellemzőjének tekinthetünk: ezek a csoportok legtöbbször kevésbé csalódnak az ellenségeikben és azok merényletre adott reakcióiban, mint a saját állítólagos szimpati-

\footnotetext{
32 Korinek László (2003): i. m. 180. o.

33 Marko Goli - Shahamak Rezaei: Radical Islamism and Migrant Integration in Denmark: An Empirical Inquiry. Journal of Strategic Security, vol. 4, no. 4, 2011, pp. 104-107.

34 Peter Waldmann (2014): i. m. 742. o.
} 
zánsaikban, az állítólagos érdekelt harmadik félben - ahogy Herfried Münkler nevezte öket -, akiket a céljaikhoz akarnak fellelkesíteni és mozgósítani. ${ }^{35}$

Az állítólagos szimpatizáns csoportok visszafogottságának okai kézenfekvők. A terrortámadások rendszerint megszorító kormányzati intézkedéseket vonnak maguk után, amelyektől az egész lakosság szenved; ha tartós fegyveres konfliktusra kerül sor, akkor az egész érintett régió, amelyben a harcot vívják, gazdaságilag visszamarad.

Csak kivételes esetekben - elsősorban akkor, ha a kormányzat viselkedik ügyetlenül - lehet számolni szélesebb lakossági csoportok szolidaritásával. Egyéb esetekben a terrorista csoportok iránti érzés inkább ambivalens ${ }^{36}$ szokott lenni, vagy a lakosság akár még el is határolódik tölük. A terrorcsoportok pedig ezáltal megint csak kényszerítve érzik magukat arra, hogy vagy mérsékelt reformirányra váltsanak, vagy külföld irányába térjenek ki. Terrorizmuskutatók valóban azt a szorult helyzetet tartják a növekvő internacionalista terrorizmus egyik fó okának, amelybe terrorista csoportok nemzeti szinten kerülnek. ${ }^{37}$

Van azonban egy olyan helyzet, amely ideáltipikus módon alkalmas arra, hogy népszerüsítse a terrorista csoportokat, és széles, zavargó erőszakkampányba engedje torkollni az egyes merényleteket. Ez a helyzet akkor áll fenn, ha külső erők veszik át a politikai hatalmat, és azt oly módon gyakorolják, amit neokolonializmusnak lehet nyilvánítani. Mellékes, hogy ez a felállás hogyan jön létre, hogy humanitárius okai vannak-e a külső beavatkozásnak, például despota, jogsértő rezsim felszámolása, vagy a beavatkozó állam átlátszó hatalompolitikai, illetve gazdasági önérdekei.

A tapasztalat azt mutatja, hogy a felszabadító csapatokra hamarosan megszállóként tekintenek, és ennek megfelelően ellenállással reagálnak rájuk. A harmadik világban a nacionalizmus láthatóan elegendő ahhoz, hogy egy rezsim elleni harcban egyesítse a különböző célokat követő csoportokat, ha ezt a rezsimet vagy külső kényszernek érzik, vagy némi plauzibilitással egy idegen hatalom kiszolgálójaként állítják be.

Nem véletlen, hogy az addig gyengének mondható síita szervezet, a libanoni Hezbollah ${ }^{38}$ katonai-politikai fellendülése egy olyan időszakra tehetö,

\footnotetext{
35 Herfried Münkler: Ältere und jüngere Formen des Terrorismus. Strategie und Organisationsstruktur. In: Werner Weidenfeld (Hrsg.): Herausforderung Terrorismus. Die Zukunft der Sicherheit. VS Verlag für Sozialwissenschaften, Wiesbaden, 2004, S. 36.

36 Korinek László (2003): i. m. 176. o.

37 R. Scott Appleby (2000): i. m. 95-99. o.

38 Augustus Richard Norton: The Role of Hezbollah in Lebanese Domestic Politics. The International Spectator, vol. 42, no. 4, 2007, pp. 476-478.
} 
amikor katonailag az ország déli része izraeliek által megszállt volt ${ }^{39} \mathrm{~A}$ palesztinok által megszállónak tartott izraeli állam, valamint Irak is további példa erre az újnak semmiképp sem mondható jelenségre.

A második nagy csoport, amely támogató potenciálként szóba jöhet az iszlám terrorizmus tekintetében, a nyugati ipari országok muszlim diaszpóráinak közösségei. Méretüket tekintve kisebbek ugyan, de számunkra nagyobb jelentőségüek, mint az iszlám kultúrkör országainak népessége. Mind Franciaországban, mind Németországban négy-négymillió körülire teszik a muszlimok lélekszámát.

Paz Reuven terrorizmuskutató a megnevezett két nagy csoport közül a diaszpóraközösségeket tartja a veszélyesebbnek..$^{40}$ Véleménye szerint a nyugat-európai politikusok és médiák ${ }^{41}$ túlzott jóhiszemüsége is oka a terrorizmus térnyerésének, mivel nem voltak hajlandók észrevenni, hogy nagyvonalú bevándorláspolitikájuk ezekben a társadalmakban radikális muszlim enklávék ${ }^{42}$ kialakulásához vezetett, amelyek egy nap esetleg majd kijátszhatják ennek a társadalomnak a jogállami-demokratikus alapszabályait. ${ }^{43}$

Németországban, Franciaországban és Nagy-Britanniában valóban nem kevés az olyan iszlám prédikátor, akik nagy vehemenciával harcolnak a nekik vendégjogot adó társadalom ellen. Azokat a radikális imámokat, akik a hazájukban nem beszélhetnek szabadon, vagy kevés meghallgatásra találnak, a mai Európa láthatóan úgy vonzza magához, mint ahogy Latin-Amerika a hetvenes-nyolcvanas években a baloldali radikális európai papokat. Az a reményük, hogy a diaszpórában nagyobb visszhangra találnak. Vajon jogos ez a remény?

Ahogy számos tanulmány mutatja, a nyugati országok bevándorlási helyzete a bevándorlókat kettős nehézség elé állítja. Elöször is etnikai, részben faji kisebbséghez tartozóként a lakosság nagy része által diszkriminálva érzik magukat. Másrészt egy olyan társadalommal találkoznak, amely magas fokon szekularizált, tehát amelyben a vallásos gyakorlatok és szokások nem

\footnotetext{
39 Bordás Mária: A terrorizmus és az iszlám fundamentalizmus az „Arab Tavasz” után Észak-Afrikában és a Közel-Keleten. Hadtudomány (online), 2015/25., 25. o. http://real.mtak.hu/23392/1/3_BORDAS MARIA.pdf

40 Paz Reuven: Middle East Islamism in the European Arena. MERIA Journal, vol. 6, no. 3, 2002. http://www.rubincenter.org/2002/09/paz-2002-09-06/

41 A terrorizmus és a média kapcsolatáról bővebben lásd Korinek László (2003): i. m. 172-174. o.

42 Randy Borum: Rethinking Radicalization. Journal of Strategic Security, vol. 4, no. 4, 2011, pp. 3-5.

43 ,... a nyugati kormányok eddigi politikája nem sok sikert hozott, sőt részben elősegítette a mostani helyzet kialakulását”. Besenyő János: „Arab tavasz” - politikai rendszerváltás az észak-afrikai arab államokban. Kül-Világ, 2011/4., 71. o.
} 
magától értődő dolgok. Mindkét probléma azt segíti elő, hogy még erősebben forduljanak ősi hitük felé. Ennek az odafordulásnak, ahogy más bevándorlókolóniáktól (például az egyesült államokbeli írek, a chilei németek) tudjuk, ebben az exponált helyzetben védelmi és identitásmegerösitő szerepe van. Az általuk megélt vallásosság tudatosabb, céltudatosabb, mint az anyatársadalomban.

Persze vannak olyan muszlimok, akik idegenben fanatikus istenfélővé válnak, de ők többnyire a kivételt erősítik, mintsem a szabályt. Az empirikus adatok inkább arra utalnak, hogy azok, akik szilárdan élik meg a hitüket (például rendszeresen látogatják a mecsetet, és gondosan eleget tesznek vallásos kötelességeiknek), viszonylag toleránsak a befogadó állam „őslakosságával”, az ő szekularizált életstílusukkal, és elítélik a vallásos terrorizmust mint az iszlám hittételekkel összeegyeztethetetlen viselkedést.

A terrorizmus egy társadalomra irányuló frontális támadással ér fel, amire csak olyanok képesek, akik belül már teljesen elszakadtak az illető társadalomtól, olyannyira, hogy egyenesen a gonoszt, az ,ellenséget” látják benne. Erre a belső eltávolodásra és az ennek kapcsán felgyülemlett dühre és gyülöletre általában csak azok képesek, akik nem kiskoruk óta élnek az adott társadalomban.

Lehetséges, hogy a bevándorlók második vagy harmadik generációja, amely már egy nyugati országban nőtt fel és ott járt iskolába, tehát „bennszülöttnek” (homegrown) $^{44}$ tekinthető, alkalomadtán lázadozik, sőt az elégedetlenségének erőszakkal ad hangot. ${ }^{45}$ Ám az effajta tüntetésnek általánosságban kevés köze van a terrorizmushoz. Ez nem a fennálló rend visszautasítását és legyőzését célozza meg, hanem inkább a sértett büszkeség megcsorbítását jelzi, azt, amikor az embert nem veszik komolyan és nem integrálják jobban a társadalomba.

Waldmann szerint az, hogy egy diaszpórabeli fiatal ember csatlakozik-e egy terrorista csoporthoz, három kritériumtól függ.

Elöször is ez kevésbé valószínű a második és harmadik generációs bevándorló esetén, mint az első generációnál, akik még a befogadó országtól független identitást őriz(het)nek.

\footnotetext{
44 Répási Krisztián: Európa az iszlamista terrorizmus árnyékán. Hadtudományi Szemle, 2013/1., 43. o. 45 „Az Európába érkező első generációs bevándorlók közül sokan nem tudtak teljesen beilleszkedni a fogadó országba, ám az integráció hiánya és az ebből fakadó radikalizáció sokkal inkább az utánuk következő nemzedékeknél vált igazán láthatóvá [...] A második generációnál jelentkező problémát már az 1980-as évek végén felnőttkorba ért fiataloknál lehetett tapasztalni, akikből később létrejött az a muzulmán eredetű szegény, a többségi társadalomtól elidegenedő városi fiatalság, amely szüleiktől eltérően jóval fogékonyabbá vált a radikális eszmékre..." Répási Krisztián: Franciaország iszlamista terrorfenyegetettsége. Nemzet és Biztonság, 2015/1., 40-41. o.
} 
Másodszor ez kevésbé jellemző az iszlámban szilárdan hívőkre, inkább az olyan meghasonlott személyekre, akik (ritkán) egy kísérletező fázis, a nyugati életstílus kipróbálása után, egyfajta visszatérésen át találnak rá ismét az eredeti hitükre.

Harmadszor az ilyen radikális elemek inkább a muszlim hitközösségek peremein jellemzők, mint annak központi intézményeiben. ${ }^{46}$

Konkrétan tehát egy radikális iszlám csoporthoz való közeledés folyamata legtöbbször három lépésben történik. Kezdetben van a diszkrimináció és a szociális elszigeteltség személyes megtapasztalása; ezt követi az újbóli vallásos ráeszmélés szakasza, ami gyakran egy vezetö - adott körülmények között akár egy rokon - befolyására egy bizonyos csoport iránti elköteleződésbe torkollik, esetleg egy bizonyos ,projekt” érdekében. ${ }^{47}$

Természetesen e három kritérium bizonyára nem elegendő a veszélyes iszlám csoportok meghatározásához, illetve létrejöttük megelőzéséhez, s kevéssé lehetséges az összes muszlimot, tehát egy több százmilliós népcsoportot gyanúsítani és állandóan megfigyelés alatt tartani.

Eltekintve a jobboldali radikális gondolkodásmódtól $1^{48}$ és attól a rengeteg „gyülöletenergiától”, amit ez jelent, az is ellene szól, hogy kontraproduktív hatása lehetne, és pont egy olyan szörnyeteget teremthetne, amelyet az ember éppen visszafogni és kontrollálni szeretne.

Perspektivikusan okosabb és célravezetőbb lenne a muszlim közösségek mérsékelt csoportjait nem veszély-, hanem információforrásként kezelni (például ténylegesen rendszeres kapcsolattartás az állami szervek és a vallási csoportok között).

Minden arra utal, hogy hiba lenne azt feltételezni, miszerint ezek a közösségek szimpatizálnak vagy szolidaritást vállalnak az eröszak-aktivistákkal. Gondoljunk csak a Charlie Hebdo elleni merénylet utáni eseményekre: az iszlám szervezetek azonnal hajlandók voltak a nyugati befogadó állam mögé állni, és egyezséget kötni vele a szabad jogállami alapszabály megőrzése érdekében.

Venni kellene a bátorságot ezeknek az erőforrásoknak a használatára és jobb mobilizálására, hiszen azokban az országokban, amelyekben jelentősebb muszlim diaszpóra él, a többséget minden bizonnyal a mérsékelt hívők képviselik, és nem a radikálisok.

Megállapítható, hogy mind az arab országokban, mind a diaszpóraközösségekben vannak olyan radikális körök, amelyek terroristák mögött állnak,

46 Peter Waldmann (2014): i. m. 743. o.

47 Uo.

48 Lásd bővebben Csánó Szabina: Radikális irányok. Fordulat, 2011/2., 147-148. o. 
méretüket és társadalmi-politikai súlyukat azonban semmiképp sem kellene túlbecsülni.

A terrorizmuskutató szempontjából ezek azért érdekesek, mert megközelíthetők, tehát elvileg kapcsolatba lehet lépni velük, fel lehet deríteni a céljaikat ${ }^{49}$, törekvéseiket és frusztrációikat, amelyek általában megegyeznek a terroristák elképzeléseivel (akiket többnyire csak a börtönben lehet meginterjúvolni).

\section{Kitekintés a nemzetközi terrorizmusra, különös tekintettel az al-Kaidára}

Kézenfekvő a kérdés: vajon a nemzetközi iszlám terrorista csoportok, föként az al-Kaida, honnan szereznek támogatást, ha sem az iszlám országokban, sem pedig a diaszpóraközösségekben nem találnak széles követői körre. A válasz az, hogy a nemzetközi terrorizmushoz általában a „duplán szétszórtak" csatlakoznak: tehát azok, akik - a muszlim hívők zömével ellentétben nemcsak egy radikális iszlám áramlathoz csatlakoztak, hanem még ezen belül is a peremre szorultak, nincs befolyásuk és jelentőségük. ${ }^{50}$

Ebből a jelentéktelenségből azonban természetesen nem következtethetünk veszélytelenségre, éppen ellenkezőleg: mivel a nemzetközi iszlám terrorizmus elemei nem kötődnek konkrét vonatkoztatási és szimpatizáns csoporthoz, amely egyrészt hordozza őket, másrészt amely előtt képviselniük kell merényleteiket, éppen ezért különösen veszélyesek. Csak egymással kapcsolatban állva és egymást őrült merénylettervekben megerősítve és túlszárnyalva, semmi nem szab határt romboló projektjeiknek.

Ez jól látható a 2004. március 11-i madridi halálos merénylet kapcsán is, amelyet eredetileg a baszk ETA szervezet nyakába varrtak. Valójában az ETA soha nem engedhetett volna meg magának egy ilyen jellegü „megamerényletet”, amely majdnem kétszáz halálos áldozatot követelt, egyszerü emberek életét, akik korán reggel a helyi vasúttal munkába igyekeztek. Ez az ETA politikai végét és megszünését jelentette volna, mert még a legfanatikusabb baszk patrióta sem fogadta volna el egy ilyen jellegủ gaztett helyénvalóságát.

A nemzetközi vagy globálisan müködő csoportok és elemek esetén ez másképp van, ezek egy bizonyos lakossági csoport elleni konkrét politikai

49 Dorothee Dienstbühl: Neue Denkweisen im Kampf gegen Terrorismus. Kriminalistik, 3/2007., S. 162. $50 \mathrm{Ez}$ az úgynevezett dupla marginalitás. Bővebben lásd Friedhelm Neidhardt: Weltweiter Terrorismus Neue Bedrohungen? Einleitung. In: Kurt Graulich - Dieter Simon (Hrsg.): Terrorismus und Rechtstaatlichkeit - Analysen, Handlungsoptionen, Perspektiven. Akademie Verlag, Berlin, 2007, S. 41-43. 
megtorlás hiányában a legbrutálisabb merényletekre (még az ABCfegyverek, azaz az atom-, biológiai és a vegyi hadviselés eszközei sem kizártak, ha a hatótávolságukban van ilyen) képesek. Tulajdonképpen ez bennük a félelmetes és veszélyes, még inkább, mint a nemzetközileg kiépített hálózatuk vagy a nemzetközi pénzforrásaik.

A nemzetközi terrorszervezetek talán legveszélyesebbike az Iszlám Állam nevü megacsoport. Minderről a Német Alkotmányvédelmi Hivatal (Bundesamt für Verfassungsschutz; BfV) 2012-es jelentése is külön említést tesz. A BfV információi szerint Németország különlegesen kedvezőtlen helyzetben van, mert egyszerre visszavonulási hely és müködési terület az iszlám terroristák számára, akik bármikor veszélyeztethetik a belső biztonságot „,különbözö dimenziójú és intenzitású merényletek formájában". ${ }^{51}$

Az Iszlám Állam jól képzett, harcban edzett, radikalizált és valószínűleg traumatizált harcosai lehet, hogy hazatérésük után otthon folytatják a háborút.

A BfV 2013-as alkotmányvédelmi jelentése végső soron megállapítja, hogy a németországi és az európai radikális iszlám térnyerését két jelenség kíséri, mégpedig ,egy példátlan propagandahullám a (dzsihád-) iszlám erők támogatására” és ,, az iszlamisták kivándorlási hulláma Szíriába”. A BfV azt is hangsúlyozza, hogy sok európai ember számára a dzsihádba való hadba vonulás és az a hajlandóság, hogy valaki az iszlámért való harc közben képes feláldozni saját magát is, egyfajta önkifejezés („mártírkultusz”). ${ }^{52}$

Az Iszlám Állam harcedzett tagjai valós veszélyt jelentenek, mert akár autonóm módon, akár parancsra elhatározhatják, hogy megtámadnak olyan „lágy” szimbolikus célpontokat, amelyek bármely demokratikus ország értékeit, rendszereit és ideológiáját reprezentálják, kegyetlenül lemészárolnak ártatlan embereket az utcán, vagy öngyilkos merényleteket követnek el. Ennek a stratégiának az oka a növekvő félelem és elbizonytalanodás, az esemény nagyfokú mediatizálása, a harci hatás fenntartható megvilágítása az egyes követők számára, és a könnyedség, amellyel az ilyen célok elérhetők. ${ }^{53}$

Így az Iszlám Állam nem csupán nagy veszélyt jelent az Európai Unió szabadsága és belső biztonsága szempontjából, hanem olyan kihívást is, amit komolyan kell venniük az uniós demokráciáknak, és amely ellen a permissziv

\footnotetext{
51 Verfassungsschutzbericht 2012. Bundesministerium des Innern, Werberdruck GmbH, Spangenberg, 2013, S. 229

52 Verfassungsschutzbericht 2013. Bundesministerium des Innern, Werberdruck GmbH, Spangenberg, 2013, S. 195.

53 Roland Christian Hoffmann-Plesch: Deutsche IS-Dschihadisten - Kriminalätiologische und kriminalpräventive Analyse des Radikalisierungsprozess Teil 1: Religionskriminologische und psychopolitische Aspekte. Kriminalistik, 12/2014., S. 699.
} 
politika már nem célravezetö. Hasonló következtetéseket olvashatunk az Europol és az unió terrorfenyegetettségét vizsgáló kiadványokban, valamint a polgári nemzetbiztonsági szolgálatok éves jelentéseiben is. ${ }^{54}$

Az Iszlám Állam elleni intézkedések azonban elkerülhetetlenül és szükségszerúen együtt járnak bizonyos személyek és szervezetek szabadságjogainak korlátozásával.

Minden egyes végrehajtott merénylet vagy merényletkísérlet után újra meg újra megállapítható, mennyire keveset tudunk a merénylőkről, és minden egyes alkalommal politikai döntésekkel próbálják meg csillapítani a nagyobb védelem és nagyobb biztonság iránti vágyat. ${ }^{55}$

\section{A terrorcsoportok szervezeti tényezői}

A terrorizmuskutatásban jelentős pozíciót elfoglaló úgynevezett hálózatteória kezdetben úgy tủnt, hogy megingathatatlan interpretációs séma.

A decentralizált hálózati konstrukció prototípusának az al-Kaida tekinthetô" ${ }^{\prime 6}$, amely mellett egyéb iszlám szervezetet is felhoznak példának. Az észak-amerikai, erősen jobboldali irányultságú keresztény ideológiában gyökeredző milíciákat is idesorolják. A hálózatokat egyfajta szervezeti válaszként értelmezik az „„új”, nemzetközileg müködő terrorizmussal kapcsolatos próbatételekre. ${ }^{57}$

Ezekkel állítják szembe az úgynevezett „,régi” terrorizmus szervezeteit (például IRA, ETA), amelyek - ha összehasonlítjuk őket az említettekkel zárt, behatárolható földrajzi müködési területre koncentrált, erősen hierarchikusan felépülő szövetségek.

Van néhány kivetnivaló ebben a tipizálásban, mégpedig elsősorban a régi és az új terrorizmus ${ }^{58}$ közötti elnagyolt differenciálás. ${ }^{59}$

54 Répási Krisztián (2015): i. m. 41. o.

55 Dorothee Dienstbühl: i. m. 162. o.

56 Bővebben lásd Tálas Péter: A terrorizmusról hét évvel 9/11 után. Nemzet és Biztonság, 2008. október, 74-75. o.

57 Bővebben lásd Krasznai Andrea: 2001. szeptember 11-e és az új típusú terrorizmus nemzetközi összefüggései. Egyetemi doktori (PhD-) értekezés. Debreceni Egyetem Történelmi és Néprajzi Doktori Iskola, Debrecen, 2011, 35-70. o.

58 Herfried Münkler: Die neuen Kriege. Der Bürger im Staat 54. Jahrgang, Heft 4, 2004, S. 180-183.; Dávid Ferenc: Terrorizmus és nemzetbiztonság az ezredforduló jogalkotásában. Szakmai Szemle, 2013/1., 42-43. o.

59 A régi és az új terrorizmus megkülönböztető jegyeit jól bemutatja a következő elemzés Tálas Péter Póti László - Takács Judit: A terrorizmus elleni küzdelem fogalmi és tartalmi keretei, különös tekintettel annak katonai dimenziójára. ZMNE Stratégiai Védelmi Kutató Központ Elemzések, 2004/3., 2. o. 
Még ha az ember elismeri is, hogy a nyolcvanas évek közepének vallási terrorizmusával beköszöntött egy új, elejétől fogva erösen nemzetközi jellegü terroristahullám, ez nem jelenti azt, hogy a szervezeti struktúrákat illetően minden új volt. Aki pontosan tanulmányozta az IRA-t és az ETA-t, az tudja, hogy elméletileg hierarchikusan strukturált szövetségekröl volt szó, amelyek azonban a gyakorlatban gyakran eltértek az elméleti modelltől.

A hétköznapokban a „fentről lefelé” parancsláncolatot viszonylag lazán kezelték, hiszen a földalatti mozgalmak körülményei közepette, egy földrajzilag szerteágazó szervezet esetén, nehéz betartani a szigorú fegyelmet és a megfelelö vezetési stílust. A felelősség és a kezdeményezés nagy része is kényszerüségből a helyi csoportvezetők kezében van, akik gyakran önkényes akciókba bocsátkoznak. A szervezet fejének gyakran nem marad más választása, mint hogy ezeket utólag jóváhagyja és képviselje a világ előtt.

Éppen az ETA-ról ${ }^{60}$ (amelynek állandóan kollektív vezetői grémiuma volt) vált ismertté az első évtizedeiben, hogy a vezetői testületekben a szervezet további katonai és politikai irányáról folytatott vita állandóan megszakadt amiatt, hogy egy alcsoport egy merénylettel magához ragadta a cselekvést, és kész tények elé állította a szövetség vezetöit.

Ugyancsak kétségeket ébreszt a Hamászról, a Hezbollahról ${ }^{61}$, a dzsihádról vagy az al-Kaidáról írt jelentések kapcsán is, hogy ezek mennyire vannak konzekvensen hálózatszerúen felépítve. Vajon azoknál az elemzéseknél, amelyek erre a modellre támaszkodnak, nem tévesztik-e gyakran össze a széles mozgalmat a szövetség szoros magjával?

Ahhoz, hogy valakit felvegyenek az al-Kaida szükebb körébe, kezdeti rituáléra, esküre van szükség, ami azonban nincs a szervezetbe lazán beágyazódó csoportoknál.

A Hezbollahnak főtitkára van, a Hamásznak pedig stabil vezetősége. Biztosan vannak véleménykülönbségek és súrlódások ennek a szervezetnek a különböző frakciói és szekciói között, de megpróbálnak rendszeresen megegyezni és közös útirányt felállítani. Nehezen beszélhetünk messzemenően autonóm al- és részszervezetekről, mert ezeket egy közös ideológiai kötelék fogja össze, és csak esetenként koordinálják akcióikat. Összehasonlításképpen inkább helyénvaló lenne egy stabil, konszolidált központi struktúra képe, amely köré rendeződik a különálló elemek széles füzére, egy folyamatosan fluktuáló törzstagsággal.

60 Répási Krisztián: A terrorizmus az Európai Unióban. Nemzet és Biztonság, 2014/3., 20. o. 61 Répási Krisztián (2013): i. m. 41. o. 
Úgy tűnik, hogy az egyetlen, konzekvensen a hálózatelv alapján felépülő mozgalomnak az észak-amerikai milíciákat tekinthetjük. Itt tényleg nincs kimondott vezetőség, csak decentralizált, egymással lazán összekapcsolt struktúrák vannak. Ezzel párhuzamosan azonban a milíciák világossá teszik az ilyen formájú szervezet érzékeny pontjait és gyengeségeit is.

Ezeket az 1990-es években még hatalmas és fenyegető mozgalomnak ábrázolták, ami számos figyelmeztető publikációra adott alkalmat, mára azonban feltünően nagy a csend körülöttük. Vajon ennek az is lehet az oka, hogy az ilyenfajta hálózatok létezése, szervezeti struktúrák hiányában, veszélyben van, és épp olyan gyorsan felbomolhatnak, mint amilyen gyorsan létrejöttek és hatalomra tettek szert?

Más szavakkal: ezeknek a hálózatstruktúráknak az operatív előnyeit nem szabad elszigetelve nézni. Rugalmasságuk és nehezen megragadhatóságuk ára a fennmaradásukra vonatkozó garancia hiánya.

Feltehetően abból kell kiindulni, hogy a terrorszervezetek számára a legkedvezőbb a kevert struktúra. Ezt, a divatos áramlatoktól függetlenül, lényegében az illegális mozgalom harcainak speciális feltételei diktálják.

Ezek a feltételek egyrészt megkövetelik, hogy az egyes csoportoknak és elemeknek egy bizonyos autonómiájuk lehessen, „hosszú pórázon” vezetve őket, és csak lazán kapcsolódjanak össze, hogy egy elem lelepleződése ne vezessen az egész szövetség széteséséhez. Másrészt azt is magukban foglalják, hogy nem lehet lemondani a központi „káderek” szilárd magjáról, ez szavatolja a harc folyamatosságát, nem téveszti szem elől a politikai-katonai célokat, és megakadályozza, hogy különböző tetszőleges egyéni akciók következtében az alakulat felaprózódjon és szétessen.

\section{Záró megjegyzések}

A vallási, mindenekelőtt az iszlamista terrorizmus, amelyre az „új terrorizmus” megtestesítőjeként tekintenek ${ }^{62}$, egyben az effajta erőszak legrégebbi formája, hiszen a nagy francia forradalom előtt, tehát 1800 előtt, elképzelhetetlen volt az erőszakos terrormódszerek nem vallásos célokból való alkalmazása.

Ily módon a terrorizmus fejlődése az utóbbi két évszázadban egy olyan ciklusnak tünik, amelyben a többi változat, az etnikai-nacionalista, az antiko-

\footnotetext{
62 Doron Zimmermann: The Transformation of Terrorism - The "New Terrorism", Impact Scalability and the Dynamic of Reciprocal Threat Perception. ETH Zürich, Zürich, 2003, pp. 9-15. [Züricher Beiträge zur Sicherheitspolitik und Konfliktforschung Nr. 67.]
} 
lonialista és a marxista terrorizmus csak köztes szakaszt alkot, és végül megint elérkezünk ahhoz a ponthoz, amelynél a fejlődés elkezdődött: a vallási terrorizmushoz.

Ami a közelebbi és távolabbi jövőt illeti, két szcenárió valószínüsíthető, ezeket a két ismert terrorizmuskutató, David Rapoport és Mark Juergensmeyer képviseli.

Az ember tekinthet úgy a terrorizmusra, mint Rapoport, tehát egy hullámformájú jelenségként. Minden egyes hullám kb. negyven évig tart, és egy fellendülési, valamint egy lecsengési szakaszból áll. Az egyik generációt, amely egy bizonyos eszmét agresszív lelkesedéssel tesz magáévá és ültet át erőszakba, a következő generáció követi, amely ugyanazért az eszméért már nem tud lelkesedni, pláne nem hajlandó érte eröszakot alkalmazni. E szerint a felfogás szerint a vallási terrorizmus tíz-tizenöt éven belül elveszíti lendületét, és bizonyos értelemben saját magát intézi el. ${ }^{63}$

Ezzel ellentétes Juergensmeyer tézise, miszerint a vallási terrorizmus a modern idők szemléleti krizisének kifejeződése és egyben arra adott válasza. Mivel ez a krízis minden elöjel szerint még jó ideig fenn fog állni, és nincs kilátásban megoldás, ez valószínúleg azt jelenti, hogy még előre nem látható ideig továbbra is együtt kell élnünk a terrorizmus átkával.

\section{IRODALOM}

Appleby, R. Scott: The Ambivalence of the Sacred: Religion, Violence, and Reconciliation. Rowman \& Littlefield Publishers, Lanham, 2000

Appleby, R. Scott: Religious Violence: The Strong, the Weak, and the Pathological. Practical Matters, iss. 5, 2012

Bartkó Róbert: A terrorizmus elleni küzdelem kriminálpolitikai kérdései. Universitas-Győr Nonprofit Kft., Györ, 2011

Besenyő János: „Arab tavasz” - politikai rendszerváltás az észak-afrikai arab államokban. Kül-Világ, 2011/4.

Bordás Mária: A terrorizmus és az iszlám fundamentalizmus az „Arab Tavasz” után ÉszakAfrikában és a Közel-Keleten. Hadtudomány (online), 2015/25. http://real.mtak.hu/23392/1/3_BORDAS_MARIA.pdf

Borum, Randy: Rethinking Radicalization. Journal of Strategic Security, vol. 4, no. 4, 2011, Csánó Szabina: Radikális irányok. Fordulat, 2011/2.

63 David C. Rapoport: The four Waves of Modern Terrorism. Current History, December 2001, pp. $47-53$. 
Csicsmann László: A magyarországi muszlim kisebbségek társadalmi integrációjának kihívásai az európai tapasztalatok tükrében. In: Hollán Miklós (szerk.): Két konferencia a hatékony államról - a hatékony államért. Budapesti Corvinus Egyetem, Budapest, 2012, 60-63. o.

Dávid Ferenc: Terrorizmus és nemzetbiztonság az ezredforduló jogalkotásában. Szakmai Szemle, 2013/1.

Detre Zoltán: A terrorizmus kialakulásának történeti háttere, megnyilvánulási formái és jelenléte a XXI. században. Bolyai Szemle, 2007/2.

Dienstbühl, Dorothee: Neue Denkweisen im Kampf gegen Terrorismus. Kriminalistik, 3/2007.

Draeger, Michael: Die Al-Qaida - eine Reaktion auf die Globalisierung? Grin Verlag, München, 2008

Emerson, Michael O. - Hartman, David: The Rise of Religious Fundamentalism. Annual Review of Sociology, vol. 32, 2006

Fischl Vilmos: Iszlám és terrorizmus, avagy civilizációk összecsapása? Hadtudomány, 2011/1.

Gál István László: A XXI. század új büncselekménytípusa: a terrorizmus finanszírozása. Rendészeti Szemle, 2009/6.

Goli, Marko - Rezaei, Shahamak: Radical Islamism and Migrant Integration in Denmark: An Empirical Inquiry. Journal of Strategic Security, vol. 4, no. 4, 2011

Hoffmann, Bruce: „Holy Terror”: The Implications of Terrorism Motivated by a religious Imperative. Studies in Conflict \& Terrorism, vol. 18, iss. 4, 1995

Hoffmann-Plesch, Roland Christian: Deutsche IS-Dschihadisten - Kriminalätiologische und kriminalpräventive Analyse des Radikalisierungsprozess Teil 1: Religionskriminologische und psychopolitische Aspekte. Kriminalistik, 12/2014.

Jenkins, Brian Michael: The US response its terrorism and its implications for transatlantic relations. In: Lindstrom, Gustav (ed.): Sift or Rift - Assessing US-EU relations after Iraq. Institute for Security Studies. Paris, 2003, pp. 210-212.

Juergensmeyer, Mark: Terror in the Name of God. Current History, November 2001

Juergensmeyer, Mark: Terror in the Mind of God - The Global Rise of Religious Violence. Third Edition Revised and Updated. University of California Press, Berkeley-Los Angeles-London, 2003

Korinek László: A terrorizmus. In: Fenyvesi Csaba - Herke Csongor (szerk.): Emlékkönyv Vargha László egyetemi tanár születésének 90. évfordulójára. Studia Iuridica Auctoritate Universitatis Pécs Publicata 132. Pécs, 2003

Korinek László: Az antiterrorista harc eszközei, különös tekintettel a büntetőjogra. In: Gál István László - Kőhalmi László (szerk.): Emlékkönyv Losonczy István professzor halálának 25. évfordulójára. Studia Iuridica Auctoritate Universitatis Pécs Publicata 138. 2005, 193-203. o.

Krasznai Andrea: 2001. szeptember 11-e és az új típusú terrorizmus nemzetközi összefüggései. Egyetemi doktori (PhD-) értekezés. Debreceni Egyetem Történelmi és Néprajzi Doktori Iskola, Debrecen, 2011 
Lewis, Bernard: The Crisis of Islam - Holy War and Unholy Terror. Modern Library Edition, New York, 2003

Münkler, Herfried: Ältere und jüngere Formen des Terrorismus. Strategie und Organisationsstruktur. In: Weidenfeld, Werner (Hrsg.): Herausforderung Terrorismus. Die Zukunft der Sicherheit. VS Verlag für Sozialwissenschaften, Wiesbaden, 2004, S. 36.

Münkler, Herfried: Die neuen Kriege. Der Bürger im Staat 54. Jahrgang, Heft 4, 2004

Nagy Mihály: Az al-Kaida és „testvérszervezeteinek” előretörése a Maghreb-térségben. Nemzet és Biztonság, 2011/5.

Neidhardt, Friedhelm: Weltweiter Terrorismus - Neue Bedrohungen? Einleitung. In: Graulich, Kurt - Simon, Dieter (Hrsg.): Terrorismus und Rechtstaatlichkeit - Analysen, Handlungsoptionen, Perspektiven. Akademie Verlag, Berlin, 2007, S. 41-43.

Norton, Augustus Richard: The Role of Hezbollah in Lebanese Domestic Politics. The International Spectator, vol. 42, no. 4, 2007

Quénivet, Noëlle: The World after September 11: Has It Really Changed? The European Journal of International Law, vol. 16, no. 3, 2015

Rapoport, David C.: The four Waves of Modern Terrorism. Current History, December 2001 Répási Krisztián: Európa az iszlamista terrorizmus árnyékán. Hadtudományi Szemle, 2013/1.

Répási Krisztián: A terrorizmus az Európai Unióban. Nemzet és Biztonság, 2014/3.

Répási Krisztián: Franciaország iszlamista terrorfenyegetettsége. Nemzet és Biztonság, 2015/1.

Reuven, Paz: Middle East Islamism in the European Arena. MERIA Journal, vol. 6, no. 3, 2002. http://www.rubincenter.org/2002/09/paz-2002-09-06/

Rohner, Dominic - Frey, Bruno S.: Blood and Ink! The common-interest-game between terrorists and the media. Public Choice, vol. 133, iss. 1-2, 2007

Salzman, Michael B.: Globalization, religious fundamentalism and the need for meaning. International Journal of Intercultural Relations, vol. 32, 2008

Scheffler, Thomas: “Apocalypticism, Inner worldly Eschatology, and Islamic Extremism”. In: Bellér-Hann, Ildikó - Gebhardt, Lisette (eds.): Religion und Gewalt: Japan, der Nahe Osten und Südasien. Orientwissenschaftliches Zentrum der Martin-Luther-Universität Halle-Wittenberg, 2003, S. 43-79. [Orientwissenschaftliche Hefte, Nr. 10.]

Scheffler, Thomas: Mit Extremisten verhandeln: Weshalb, wann und wie? In: Dialog mit der islamischen Welt. Auswärtiges Amt. Edition Diplomatie, Berlin, 2005, S. 79-81.

Schwind, Hans-Dieter: Kriminologie. 21. neu bearbeitete und erweiterte Auflage. Kriminalistik Verl., Heidelberg, 2011

Tálas Péter - Póti László - Takács Judit: A terrorizmus elleni küzdelem fogalmi és tartalmi keretei, különös tekintettel annak katonai dimenziójára. ZMNE Stratégiai Védelmi Kutató Központ Elemzések, 2004/3.

Tálas Péter: A terrorizmusról hét évvel 9/11 után. Nemzet és Biztonság, 2008. október Thompson, Robin L.: Radicalization and the Use of Social Media. Journal of Strategic Security, vol. 4, no. 4, 2011 
Waldmann, Peter: Das terroristische Kalkül und seine Erfolgsaussichten. Velbrück Online Magazin, 2002

Waldmann, Peter: Islamistischer Terrorismus. Kriminalistik, 12/2014.

Walter, Christian: Defining Terrorism in National and International Law. In: Walter, Christian - Vöneky, Silja - Röben, Volker - Schorkopf, Frank (eds.): Terrorism as a Challenge for National and International Law: Security versus Liberty? Springer, Berlin-Heidelberg, 2004, pp. 24-29.

Zimmermann, Doron: The Transformation of Terrorism - The "New Terrorism", Impact Scalability and the Dynamic of Reciprocal Threat Perception. ETH Zürich, Zürich, 2003 [Züricher Beiträge zur Sicherheitspolitik und Konfliktforschung Nr. 67.]

Zimmermann, Ekkart: Globalization and Terrorism. European Journal of Political Economy, vol. 27, 2011 